\title{
Application of zeolites for radium removal from mine water
}

\author{
Stanisław Chałupnik • Wojciech Franus • \\ Malgorzata Wysocka • Grzegorz Gzyl
}

Received: 7 February 2013 / Accepted: 28 May 2013 / Published online: 24 July 2013

(C) The Author(s) 2013. This article is published with open access at Springerlink.com

\begin{abstract}
For removal of radium from saline waters in Upper Silesian mines, several methods of purification have been developed. The most efficient one is based on application of barium chloride, which was implemented in full technical scale in two Polish coal mines several years ago. Very good results of purification have been achieved - the removal efficiency exceeding $95 \%$ of the initial activity. Another possibility for the removal of different ions from salty waters and brines is the application of zeolites. We found that technique as a very promising method for removal of not only radium isotopes from mine waters but also other ions (barium, iron, manganese). Treatment of several various water samples has been done to assess the removal efficiency for natural radionuclides. Preliminary results show very good effects for radium isotopes as well as for barium ions. In the paper, a short description of laboratory results of the purification of mine waters with application of synthetic zeolites is presented.
\end{abstract}

Keywords Natural radioactivity $\cdot$ Radium $\cdot$ Radioactive waters $\cdot$ Brines $\cdot$ Coal mines $\cdot$ Purification $\cdot$ Zeolites

\section{Introduction}

The Upper Silesian Coal Basin (USCB) is located in the southwestern part of Poland (Fig. 1). Presently, Silesian underground coal mines extract about 90 million tons of coal

Responsible Editor: Philippe Garrigues.

S. Chałupnik $(\bowtie) \cdot$ M. Wysocka $\cdot$ G. Gzyl

Central Mining Institute, Pl. Gwarkow 1,

40-166 Katowice, Poland

e-mail: s.chalupnik@gig.eu

W. Franus

Lublin University of Technology, ul. Nadbystrzycka 38D,

20-618 Lublin, Poland per year. The depth of mine workings is from 350 to $1,100 \mathrm{~m}$. The geological structure of the Upper Silesian Coal Basin is very complicated and differentiated with numerous faults and other tectonic dislocations. The mining activity is causing destruction of the strata, leading to the increase of permeability. Two hydrological regions of the Coal Basin are recognized. The first region is located in southern and western Silesia, where there are thick strata of sediments covering carboniferous formation. The cover of up to $700 \mathrm{~m}$ is built mainly by Miocene clays and silts. Such strata restrict migration of water and gases. In the second region located in the northern and eastern part, Miocene deposits do not occur. Carboniferous strata are covered either by slightly compacted Quaternary sediments or numerous outcrops of coal seams. The oldest formations of this area comprise strongly fissured and isolated sediments of Permian or Triassic limestone. These formations enable very easy migration of water and gases (Różkowski 1978).

Underground coal exploitation in Upper Silesia is a source of an additional and unexpected contaminant of the natural environment - radioactivity. In many coal mines, located in USCB, waters with enhanced radium content occur (Tomza and Lebecka 1981). Sometimes in radiumbearing brines, barium ions of concentrations up to $2 \mathrm{~g} / \mathrm{l}$ are also present. Such waters - not often met in nature-are classified as radium-bearing type A waters. In the so-called type $\mathrm{B}$ waters, barium ions do not occur, but there $\mathrm{are}^{\mathrm{SO}_{4}}{ }^{-2}$ ions $(<5 \mathrm{~g} / \mathrm{l})$. The presence of barium $\left(\mathrm{Ba}^{2+}\right)$ in the waters is the most important factor for the further behavior of radium isotopes in mine galleries or on the surface. From type A waters, radium and barium always co-precipitate as sulfates, when mixed with any water containing sulfate ions. As a result of the precipitation, barium sulfate deposits with highly enhanced radium concentrations are formed (Lebecka et al. 1985; Lebecka et al. 1994; Michalik et al. 2002; Chałupnik and Wysocka 2009). The total activity of radium isotopes in these sediments may sometimes reach 


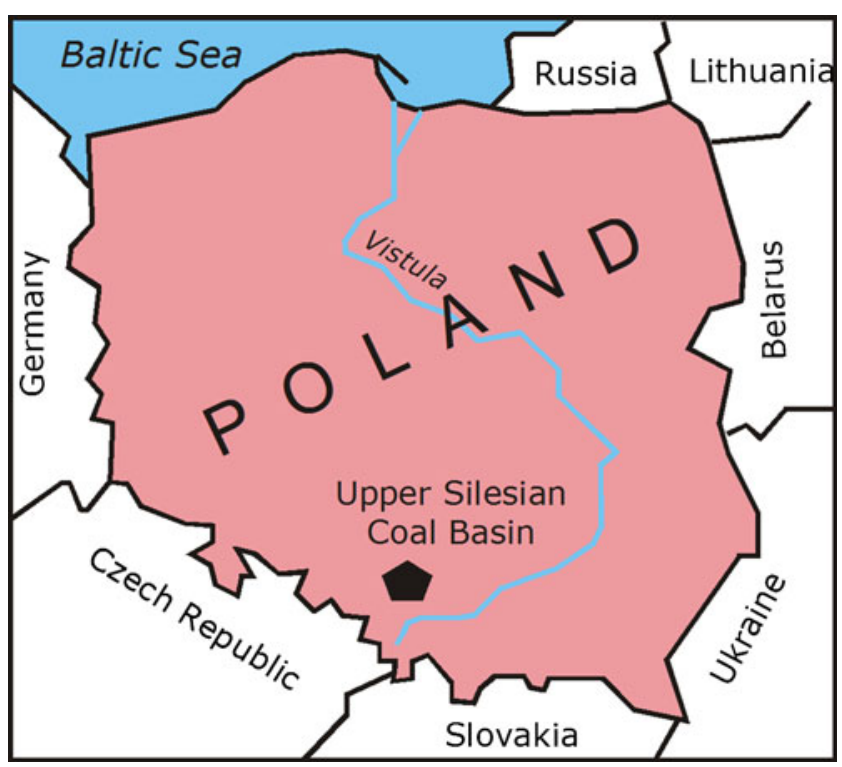

Fig. 1 Location of Upper Silesian Coal Basin

$400 \mathrm{kBq} / \mathrm{kg}$, while the average radium content in soil is $25 \mathrm{~Bq} / \mathrm{kg}$ (UNSCEAR 2000). Due to the lack of barium carrier in radium-bearing type $\mathrm{B}$ waters, precipitation does not occur. It is the reason why the increase of radium content in sediments is much lower than the ones which originated from type A waters.

In the last decade, the decrease of radium activity in discharged underground waters is mainly due to the purification of B-type brines in Piast Colliery which started in 1999 and the construction of another treatment station in Ziemowit mine in 2006. In Piast mine, the implementation of the treatment technology on deeper horizons in the mine caused the decrease of radium release from the mine to the level of $150 \mathrm{MBq}$ /day to $60 \mathrm{MBq}$ /day of ${ }^{226} \mathrm{Ra}$ and $90 \mathrm{MBq}$ /day of ${ }^{228} \mathrm{Ra}$ (Chałupnik and Wysocka 2008). Similar results have been achieved in the second underground coal mine, Ziemowit. Additionally, the purification system for the second horizon of Piast mine is under design, and it is expected to solve most of the problems with radium contamination of river waters in that part of the Upper Silesia region. The process of water treatment is based on the dissolution of barium chloride and immediate co-precipitation of barium and radium ions as sulfates. This reaction is possible due to the surplus of sulfate ions present in brines in concentrations 30-50 times higher than required for stoichiometric reaction. The only problem is due to chemical properties of barium chloride. This chemical is potentially dangerous for miners. It is hygroscopic, causing technical problems during feeding in a very humid mine atmosphere. Therefore, another option has been tested: the application of zeolites for removal of radium isotopes and some heavy metals from mine waters and drinking waters. The results seem to be very promising.
Different techniques of water treatment

Water treatment technologies for removal of natural radionuclides (radium) have been developed at first for the uranium mining and milling industry (Nixon et al. 1983). This problem is well known since for many years, it was a very important issue to diminish the environmental pollution caused by the uranium industry. Usually, treatment techniques are based on the application of barium chloride, which is added as a carrier for further radium co-precipitation as sulfate (Gordon and Lowley 1957). The radioactive suspension is removed in sand filters or other mechanical ones (Ring et al. 1982; Hynes et al. 1985). Very common is also the application of cheaper methods like bioremediation (Luan et al. 2012), but the removal efficiency for such a solution is often unstable and dependent on different factors, such as atmospheric conditions (Groudev et al. 2008). Methods for treatment of effluents from the uranium industry are under continuous improvements; a lot of experiments are performed to test new and sometimes rather expensive techniques, like titanate nanofibers (Yang et al. 2008). This material can be used for the removal of radium, strontium, barium, and lead radionuclides from wastewater, being a potential adsorbent not only in the uranium industry.

Water treatment for removal of pollutants and radioactivity is often necessary for drinking water supplies, especially from underground aquifers. In different countries, like Finland, Sweden, or Austria, this problem is so important that a lot of investigations have been done to solve it (Annanmäki and Turtiainen 2000). In some of these waters, radium and uranium are present together, becoming a potential threat for the local communities (Drinking Water Directive 1998; Stehlik and Friedmann 1989). In the USA, the Environmental Protection Agency enforced regulations concerning maximum radium concentration in drinking water (CFR40 2000); therefore, treatment technologies had to be applied for water supplies throughout the country. Drinking water treatment is done usually with the application of aeration. $\mathrm{Mn}$ - and $\mathrm{Fe}$-oxyhydrates, the byproduct from treatment processes, are excellent scavengers for radium isotopes (Annanmäki and Turtiainen 2000). Other methods of drinking water treatment involve ion exchange resins by adsorption on special filters with manganese dioxide, with application of reverse osmosis or polymeric columns. Radium ions are being removed during this process (Miro et al. 2008; Baeza et al. 2012; Deng 2005). An application of zeolite for removal of radionuclides from drinking water has been reported by scientists from Estonia (Lumiste et. al. 2012).

In non-uranium industries, like coal mining, radium removal from mine water is not very common (Patent 1996; Chałupnik and Wysocka 2008). It may be important in oil and gas exploitation but mostly due to the technical problem with scaling of pipelines; therefore, removal of radium 
(together with non-radioactive barium and strontium) is done (Abo-Elmagd et al. 2010), or just the opposite-special chemicals are used to prevent this process (Varskog et al. 2004). In mining industries, special features of mine water must be taken into account when investigations or development of treatment technologies are performed. A very important issue is the high salinity of brines, reaching or even exceeding $100 \mathrm{~g} / \mathrm{l}$ (Lebecka et al. 1992). Another problem is related with the volume of water required for purification. In some Polish coal mines, the outflow from a single horizon in the mine may reach $15-20 \mathrm{~m}^{3}$ per minute (roughly $30,000 \mathrm{~m}^{3}$ per day). Additionally, the treatment should be done in underground galleries to prevent pollution of the natural environment, even at the settling ponds on the land surface. Due to these circumstances, costs of the treatment installations are high; for instance, the cost of construction of the treatment station in one of the coal mines was as high as 5 million euro. Moreover, the application of barium chloride (a very poisonous material) and the need of continuous feeding of the reagent into the treated water (up to $1,000 \mathrm{~kg}$ per day) make the exploitation of the treatment station expensive.

A possible solution for a passive technology might be the application of zeolite materials (natural and synthetic ones) for the removal of not only radium but also some other pollutants from mine water. Application of zeolites is expected to be significantly cheaper than the methods used so far; however, a detailed financial study has to be done in the future. Zeolites have been applied for removal of heavy metals from groundwater (Lumiste et al. 2012) and similar pollutants from different wastewaters (Wang and Peng 2010; Shevade and Ford 2004; Payne and Abdel-Fattah 2005), while applications for mine water treatment are relatively rare (Wingenfelder et al. 2005). In some technologies, zeolite is being used as a "supporting medium" for additional cleaning after application of a main treatment method like wetlands, sand filters, limestone pebbles, etc. (Lizama et al. 2012; Lumiste et al. 2012).

\section{Properties of zeolites}

Natural zeolites are aluminosilicate minerals having a porous structure, which can adsorb a lot of stable cations $\left(\mathrm{Ca}^{2+}, \mathrm{Mg}^{2+}\right.$, and $\left.\mathrm{Ba}^{2+}\right)$, gases, and also radionuclides, for instance, radium isotopes. Therefore, such materials are known as "molecular sieves". The most common natural zeolites are as follows: mordenite, chabazite, clinoptilite, natrolite, and stilbite. Until now, more than 40 different natural zeolites have been identified. Due to contamination with other minerals, natural zeolites are excluded from certain applications. For such purposes, synthetic zeolites are produced (Panek et al. 2011; Franus 2012). Zeolites are used for water purification as catalysts in nuclear industry, although their largest application is the production of softeners for laundry detergents.
Nowadays, more than 150 types of synthetic zeolite are known. The most important types are $\mathrm{NaP}$ and $\mathrm{Na}-\mathrm{X}$ zeolites due to the presence of interconnected systems of microchannels. At Technical University in Lublin, Poland, a prototype device for the production of synthetic zeolites has been constructed. In this system, up to $30 \mathrm{~kg}$ of zeolitic material can be produced in each cycle from fly ash (Franus and Wdowin 2009). As some of the fly ash may contain an elevated concentration of natural radionuclides, the natural radioactivity of synthetic zeolites should be monitored. The concentration of zeolitic minerals in the final product varies from 50 to $95 \%$. The highest purity can be achieved for sodalite, but the average diameter of pores in this material is rather low $(0.25 \mathrm{~nm})$, reducing significantly the applicability of this product. Lower efficiency of production (50-65\%) has been achieved for other types of zeolite, like the NaP1 material (average diameter of pores $0.45 \mathrm{~nm}$ ) and $\mathrm{Na}-\mathrm{X}$ zeolite, in which pores are having an average size of $0.70 \mathrm{~nm}$. These materials are more suitable for industrial applications, like water treatment. Other minerals present in the final product are mulite and quartz. For the laboratory tests, the zeolite NaP1 has been chosen.

\section{The scope of purification laboratory tests}

For the measurements of radium in the liquid sample, the radiochemical method has been applied based on coprecipitation of radium isotopes with a barium carrier. The resulting precipitate is mixed with the gelling scintillating cocktail LumaGelTM. The samples are measured in a lowlevel liquid scintillation spectrometer Quantulus ${ }^{\mathrm{TM}}$. This method enables simultaneous measurement of two radium isotopes, ${ }^{226} \mathrm{Ra}$ and ${ }^{228} \mathrm{Ra}$. The detection limits are very low: $0.002 \mathrm{kBq} / \mathrm{m} 3$ in the case of ${ }^{226} \mathrm{Ra}$ and $0.020 \mathrm{kBq} / \mathrm{m}^{3}$ for ${ }^{228} \mathrm{Ra}$, when the initial sample volume is 11 and the counting time is $1 \mathrm{~h}$ (Chałupnik and Lebecka 1993).

Measurements of radioactivity of the zeolite prior to experiments and afterwards have been performed with the application of low-background gamma spectrometry. Samples have been dried at first, then transferred to 0.61 Marinelli beakers and measured; the counting time for a single sample equalled $24 \mathrm{~h}$. The detection limit for gammaemitting radionuclides is below $1 \mathrm{~Bq} / \mathrm{kg}$ (Michalik et al. 2002).

\section{Laboratory experiments}

The laboratory experiments have been performed in the following way. The chosen amount of the mixture of zeolite with the sand and gravel (to increase the permeability) has been placed in a column with a total volume of 601 . The 
water sample with a volume of 301 was poured gently into the column. The opening of the valve at the bottom of the column allowed the filtration of the sample through the bed, leading to the removal of radionuclides and some stable elements by the zeolite. The aliquots with a volume of $2-$ 31 have been collected and analyzed. Table 1 describes the water samples used in the tests.

\section{Radium removal from "synthetic" drinking water}

For the production of the filtration mixture, $20 \mathrm{~kg}$ of sand, $12.5 \mathrm{~kg}$ of gravel, and $1.5 \mathrm{~kg}$ of NaP1 zeolite have been used. This mixture has been placed in the column, and 301 of synthetic drinking water (low conductivity) was used for the first experiment. The average volume of samples after filtration was 2.51 , and results of the treatment are shown in Table 2.

It can be clearly seen that the results of treatment are very good. The efficiency of radium removal from water exceeds $90 \%$ for all samples, except the last one. Even in this case, the efficiency is higher than $80 \%$. The most difficult problem in this experiment was leaching very fine particles of zeolite from the mixture. Therefore, at the end of the experiment, the drop of the efficiency was probably caused by this effect, and there was a need to improve the quality of zeolites, i.e., to produce coarser grains of the material. Despite those problems, results of the treatment proved the capabilities of the application of zeolites for removal of radionuclides from drinking water, which is very important for some underground drinking water supplies (Drinking Water Directive 1998; Decree 2007; Vornehm 2009).

\section{Radium removal from "synthetic" barium-bearing water}

In this experiment, the most important issue was to assess the capacity of the zeolite for barium removal. Barium is sometimes present in saline mine waters in significant concentrations, reaching 2-3 g/l. In this case, the barium content in the sample was even higher, $6 \mathrm{~g} / \mathrm{l}$. Additionally, radium isotopes have been added to the water sample with a total volume of
301 . In this case, the filtration mixture consisted of $34.5 \mathrm{~kg}$ of quartz sand and $2.2 \mathrm{~kg}$ of zeolite. The results of purification are shown in Table 3. Also, in this case, the average volume of the sample aliquot was 2.51 .

It can be seen that about 12.51 of the barium-bearing water has been very finely purified, and only traces of radium and barium were present in the water after filtration. The removal efficiency exceeded $98 \%$. Afterwards, the purification efficiency dropped very quickly, showing the saturation of the zeolite in the column with barium. The amount of the zeolite in the column was $2.2 \mathrm{~kg}$, and approximately $80 \mathrm{~g}$ of barium has been removed from the solution. The rough estimation shows that $1 \mathrm{~kg}$ of zeolite is able to remove $40 \mathrm{~g}$ of barium from the water and possibly similar amount of other stable elements from the solution like manganese or iron. The experiment assured us that the problem with overload of the column capacity can happen in cases when stable pollutants are present in water in elevated concentrations and the volume of filtrated water is significant, too. This is a proof that treatment of radium- and barium-bearing waters would be difficult or impossible due to the high barium content and fast loss of adsorption capabilities of the zeolite. If the concentration of barium in mine water is low, then the applicability of zeolite is possible and should lead to the positive results of purification.

\section{Radium removal from mine water}

The water sample for experiments has been collected in the underground water galleries of one of the collieries in the Upper Silesian Coal Basin. The salinity (TDS) exceeds $100 \mathrm{~g} / \mathrm{l}$, and the concentration of radium isotopes is clearly enhanced. The water contains few grams per liter of sulfate ions, but barium is not present in the water. The filtration mixture consisted of $20 \mathrm{~kg}$ of sand, $12.5 \mathrm{~kg}$ of gravel, and $1.5 \mathrm{~kg}$ of NaP1 zeolite. Results of the water treatment are presented in Table 4.

For the experiment, 301 of mine water was used, and the average volume of the treated water was 31 . Except for the two first samples, the purification efficiency exceeded $98 \%$, despite the fact that the total volume of purified water was

Table 1 Description of water samples used in experiments

\begin{tabular}{|c|c|c|c|c|}
\hline No. & Sample description & $\mathrm{Ra}-226\left(\mathrm{kBq} / \mathrm{m}^{3}\right)$ & $\mathrm{Ra}-228\left(\mathrm{kBq} / \mathrm{m}^{3}\right)$ & Remarks \\
\hline 1 & Synthetic drinking water (sample A) & $0.216 \pm 0.034^{\mathrm{a}}$ & $1.01 \pm 0.27$ & Deionized water with added radium standard solutions \\
\hline 2 & $\begin{array}{l}\text { Artificial "barium-bearing" water } \\
\text { (sample B) }\end{array}$ & $1.059 \pm 0.045$ & $1.97 \pm 0.47$ & Barium conc. $6 \mathrm{~g} / \mathrm{l}$, conductivity $9,650 \mu \mathrm{S} / \mathrm{cm}$ \\
\hline 3 & Mine water $\mathrm{C}$ & $1.833 \pm 0.296$ & $3.16 \pm 0.51$ & Conductivity $112,400 \mu \mathrm{S} / \mathrm{cm}$ \\
\hline 4 & Mine water D & $4.216 \pm 0.534$ & $7.81 \pm 1.46$ & Conductivity $119,000 \mu \mathrm{S} / \mathrm{cm}$ \\
\hline
\end{tabular}

\footnotetext{
${ }^{a}$ Budget of uncertainty is defined as the sum of the uncertainty of the sample volume, the uncertainty of the activity of the standard solution, the uncertainty in counting of the standard solution, and the uncertainty of the corrected count rates of the measured sample
} 
Table 2 Results of purification of synthetic drinking water

\begin{tabular}{llll}
\hline No. & Sample description & $\begin{array}{l}\text { Ra-226 } \\
\text { concentration } \\
\left(\mathrm{kBq} / \mathrm{m}^{3}\right)\end{array}$ & $\begin{array}{l}\text { Ra-228 } \\
\text { concentration } \\
\left(\mathrm{kBq} / \mathrm{m}^{3}\right)\end{array}$ \\
\hline 1 & $\begin{array}{l}\text { Raw water } \\
\text { (before treatment) }\end{array}$ & $0.216 \pm 0.034$ & $1.01 \pm 0.27$ \\
2 & Sample A-1/1 & $<0.003$ & $<0.06$ \\
3 & Sample A-1/2 & $<0.003$ & $<0.06$ \\
4 & Sample A-1/3 & $<0.007$ & $<0.06$ \\
5 & Sample A-1/4 & $0.019 \pm 0.008$ & $<0.06$ \\
6 & Sample A-1/5 & $0.041 \pm 0.009$ & $0.07 \pm 0.06$ \\
7 & Sample A-1/6 & $<0.003$ & $<0.08$ \\
8 & Sample A-1/7 & $<0.003$ & $<0.06$ \\
9 & Sample A-1/8 & $<0.007$ & $<0.03$ \\
10 & Sample A-1/9 & $0.008 \pm 0.007$ & $<0.03$ \\
11 & Sample A-1/10 & $0.013 \pm 0.008$ & $0.07 \pm 0.06$ \\
12 & Sample A-1/11 & $0.041 \pm 0.011$ & $0.09 \pm 0.07$ \\
\hline
\end{tabular}

30 1. The result was a confirmation of the possibility of radium removal from very salty waters (brines) with application of a zeolite material.

\section{Radium removal from mine water-second experiment}

Another water sample has been collected from the outflow in one of the underground galleries of the same mine as the previous sample, but this time, the total volume of the water sample was 150 l. Again, the salinity of the water was higher than $100 \mathrm{~g} / \mathrm{l}$, and the water contained no barium but sulfate ions and radium isotopes. The filtration mixture consisted of $26.5 \mathrm{~kg}$ of sand and $2.0 \mathrm{~kg}$ of zeolite NaP1. The total volume of the treated water was $140 \mathrm{l}$, and the average volume of the sub-sample was 51 . Results are presented in Table 5.

In this experiment, a larger water sample has been used. The sample was the largest one possible to be collected in the

Table 3 Radium removal from synthetic barium-bearing water

\begin{tabular}{llll}
\hline No. & Sample description & $\begin{array}{l}\text { Ra-226 } \\
\text { concentration } \\
\left(\mathrm{kBq} / \mathrm{m}^{3}\right)\end{array}$ & $\begin{array}{l}\text { Ra-228 } \\
\text { concentration } \\
\left(\mathrm{kBq} / \mathrm{m}^{3}\right)\end{array}$ \\
\hline 1 & $\begin{array}{c}\text { Synthetic barium } \\
\text { bearing water }\end{array}$ & $1.059 \pm 0.084$ & $1.97 \pm 0.47$ \\
2 & Sample B-4/1 & $0.025 \pm 0.008$ & $<0.06$ \\
3 & Sample B-4/2 & $0.029 \pm 0.008$ & $<0.06$ \\
4 & Sample B-4/3 & $<0.007$ & $<0.06$ \\
5 & Sample B-4/4 & $0.009 \pm 0.007$ & $<0.05$ \\
6 & Sample B-4/5 & $0.040 \pm 0.009$ & $<0.06$ \\
7 & Sample B-4/6 & $0.292 \pm 0.034$ & $0.55 \pm 0.16$ \\
8 & Sample B-4/7 & $0.485 \pm 0.057$ & $1.14 \pm 0.32$ \\
\hline
\end{tabular}

Table 4 Results of purification of mine water C

\begin{tabular}{llll}
\hline No. & Sample description & $\begin{array}{l}\text { Ra-226 } \\
\text { concentration } \\
\left(\mathrm{kBq} / \mathrm{m}^{3}\right)\end{array}$ & $\begin{array}{l}\text { Ra-228 } \\
\text { concentration } \\
\left(\mathrm{kBq} / \mathrm{m}^{3}\right)\end{array}$ \\
\hline 1 & $\begin{array}{c}\text { Sample C (mine water } \\
\text { from water galleries) }\end{array}$ & $1.833 \pm 0.296$ & $3.16 \pm 0.51$ \\
2 & Sample C-2/1 & $0.151 \pm 0.010$ & $0.20 \pm 0.05$ \\
3 & Sample C-2/2 & $0.070 \pm 0.007$ & $0.11 \pm 0.04$ \\
4 & Sample C-2/3 & $0.022 \pm 0.005$ & $<0.03$ \\
5 & Sample C-2/3 & $0.024 \pm 0.005$ & $<0.03$ \\
6 & Sample C-2/4 & $0.027 \pm 0.005$ & $<0.03$ \\
7 & Sample C-2/5 & $0.013 \pm 0.004$ & $<0.03$ \\
8 & Sample C-2/6 & $0.033 \pm 0.005$ & $<0.03$ \\
9 & Sample C-2/7 & $0.013 \pm 0.004$ & $<0.02$ \\
\hline
\end{tabular}

underground mine and transported to the surface. The main purpose of the experiment was the estimation of the adsorption capacity of the zeolite during the long-term treatment. It can be clearly seen that very good purification efficiency has been achieved - above $98 \%$ for both radium isotopes. The gamma spectrometry measurements of the filtration bed showed that the total activity of radium, adsorbed on zeolite, was approximately $1,500 \mathrm{~Bq}(500 \mathrm{~Bq}$ of Ra-226 and $1,000 \mathrm{~Bq}$ of Ra-228); in mass units, it equals roughly $2 \times 10^{-11} \mathrm{~g}$. It means that the overload of zeolite could be only the result of adsorption of stable elements like strontium or manganese. The chemical analysis of these pollutants showed that this effect may occur after filtration of at least $1.2 \mathrm{~m}^{3}$ of such brine.

In the conditions in underground galleries, the main problem would be the mechanical suspension present in brines as

Table 5 Results of purification of mine water D

\begin{tabular}{llll}
\hline No. & Sample description & $\begin{array}{l}\text { Ra-226 } \\
\text { concentration } \\
\left(\mathrm{kBq} / \mathrm{m}^{3}\right)\end{array}$ & $\begin{array}{l}\text { Ra-228 } \\
\text { concentration } \\
\left(\mathrm{kBq} / \mathrm{m}^{3}\right)\end{array}$ \\
\hline 1 & $\begin{array}{c}\text { Sample D (brine from } \\
\text { the underground gallery) }\end{array}$ & $4.216 \pm 0.534$ & $7.81 \pm 1.46$ \\
2 & Sample D-2/1 & $0.038 \pm 0.009$ & $0.10 \pm 0.06$ \\
3 & Sample D-2/3 & $0.014 \pm 0.007$ & $<0.05$ \\
4 & Sample D-2/5 & $0.024 \pm 0.008$ & $0.06 \pm 0.06$ \\
5 & Sample D-2/7 & $0.055 \pm 0.009$ & $0.07 \pm 0.06$ \\
6 & Sample D-2/9 & $0.025 \pm 0.008$ & $<0.05$ \\
7 & Sample D-2/11 & $0.032 \pm 0.009$ & $<0.05$ \\
8 & Sample D-2/13 & $0.035 \pm 0.009$ & $0.09 \pm 0.06$ \\
9 & Sample D-2/15 & $0.032 \pm 0.009$ & $0.09 \pm 0.06$ \\
10 & Sample D-2/17 & $0.007 \pm 0.007$ & $<0.05$ \\
11 & Sample D-2/19 & $0.016 \pm 0.007$ & $<0.05$ \\
12 & Sample D-2/21 & $0.011 \pm 0.007$ & $<0.05$ \\
13 & Sample D-2/23 & $0.037 \pm 0.009$ & $0.10 \pm 0.06$ \\
14 & Sample D-2/25 & $0.007 \pm 0.007$ & $<0.05$ \\
\hline
\end{tabular}


a result of exploitation. Therefore, to estimate the possibility of application of a zeolite material for underground treatment of mine waters, it will be necessary to perform underground tests of the method.

\section{Conclusions}

The aim of the laboratory experiments was to check the possibility of zeolite application for removal of radium from mine water. For the experiments, four different water samples were used: two artificial ones and two brines from a chosen colliery.

It can be clearly seen that the results of purification were very good. The efficiency of radium removal from water exceeded $90 \%$ for all samples, except the synthetic barium-bearing water, when the purification efficiency dropped significantly after overloading of the filtration bed. The most difficult problem in these experiments was the leaching of very fine particles of zeolite from the column. Therefore, there is a need to improve the quality of zeolite and produce coarser grains of the material.

The estimation of the capacity of zeolite for radium isotopes showed that it would be possible to use such method for the treatment of radium-bearing waters. On the other hand, in underground galleries, the main problem would be the mechanical suspension present in brines as a result of exploitation. Therefore, it will be necessary to perform underground tests of the method.

The main goal of these experiments was to find an inexpensive passive method for the treatment of a huge volume of mine waters to remove radium isotopes and some other stable pollutants. Additionally, the method must fulfill specific requirements of the mining industry - waste waters in underground mines contain high concentrations of mechanical suspension, clogging very efficiently all filters. The application of zeolite materials together with fly ash for the construction of passive barriers seems to be such a solution. As the spoils after treatment are having enhanced radioactivity, it is necessary to dump such a material to old galleries or exploited out zones (gobbins). The mixture of zeolite with fly ash and sand must be treated as a disposable material. No recovery is predicted to avoid additional radiation hazard for miners. Therefore, any application of ion exchange resins, nanofibers, or polymers in the mining industry is excluded, mostly due to the costs.

Open Access This article is distributed under the terms of the Creative Commons Attribution License which permits any use, distribution, and reproduction in any medium, provided the original author(s) and the source are credited.

\section{References}

Abo-Elmagd M, Soliman HA, Salman KA, El-Masry NM (2010) Radiological hazards of TENORM in the wasted petroleum pipes. $\mathrm{J}$ Environ Radioact 101(1):51-54. doi:10.1016/j.jenvrad.2009.08.016
Annanmäki M, Turtiainen T (2000) Treatment techniques for removing natural radionuclides from drinking water [final report of the TENAWA project STUK-A169]. STUK Radiation and Nuclear Safety Authority, Helsinki

Baeza A, Salas A, Guillén J (2012) (2012) Adaptation of working conditions of an operating drinking water treatment plant to remove naturally occurring radionuclides. Water Air Soil Pollut 223:5057-5069

CFR 40 (2000) Code of Federal Regulations 40, Part 141. National primary drinking water regulations, with minor changes in 2004

Chałupnik S, Lebecka J (1993) Determination of ${ }^{226} \mathrm{Ra},{ }^{228} \mathrm{Ra},{ }^{224} \mathrm{Ra}$ in water and aqueous solutions by liquid scintillation counting. In: Liquid scintillation spectrometry 1992. Radiocarbon, Tucson

Chałupnik S, Wysocka M (2008) Radium removal from mine waters in underground installations. J Environ Radioact 99(10):1548-1552

Chałupnik S, Wysocka M (2009) Radium balance in discharge waters from coal mines in Poland the ecological impact of underground water treatment. Radioprotection 44(5):813-820

Decree (2007) Rozporzadzenie Ministra Zdrowia z dnia 29 marca 2007r. w sprawie jakości wody przeznaczonej do spożycia przez ludzi. Dz. U. z 2007r. Nr 61, poz. 417

Deng S (2005) Polymeric adsorbent for radium removal from groundwater. Adsorption 11:805-809

Drinking Water Directive (1998) Drinking Water Directive 98/83/EC, European Commission 1998

Franus W (2012) Characterization of X-type zeolite prepared from coal fly ash. Pol J Environ Stud 2:337-343

Franus W, Wdowin M (2009) Synthesis of (Na-X) zeolitic material from $\mathrm{F}$ class fly ash-laboratory and pilot plant tests. In: International clay conference: Castellaneta Marina, Italy, 14-20 September 2009, Micro et Nano Scientiae Mare Magnum, XIV International Clay Conference, Book of Abstracts, vol. II., p. 105

Gordon L, Lowley K (1957) Coprecipitation of radium with barium sulphate. Anal Chem 29(1):34-37

Groudev S, Georgiev P, Spasova I, Nicolova M (2008) Bioremediation of acid mine drainage in a uranium deposit. Hydrometallurgy 94:93-99

Hynes TP, Meadley T, Thompson N (1985) Effluent treatment experience at a high grade uranium mine. In: Proc. annual conf. of the Canadian Society for Civil Engineering and the 7th Canadian hydrotechnical conf., Saskatoon, Saskatchewan, Canada, vol.3 pp. 263-183

Lebecka J et al. (1985) Monitoring of radiation exposure from different natural sources in Polish coal mines. In: International conference on occupational safety in mining, vol.2. Toronto, Canadian $\mathrm{Nu}$ clear Association

Lebecka J, Chałupnik S, Śliwka M: Wyniki badań zachowania się radu podczas transportu stonych wód rurociagami (na przyktadzie kolektora wód stonych OLZA). (Results of investigations of radium behaviour in pipelines on example of OLZA pipeline) Wiadomości Górnicze 5/92, Katowice 1992 (in Polish).

Lebecka J, Chałupnik S, Wysocka M (1994) Radioactivity of mine waters in Upper Silesian Coal Basin, and its influence on natural environment. In: $5^{\text {th }}$ international mine water congress. Nottingham, International Mine Water Association

Lizama AK, Fletcher TD, Sun G (2012) The effect of substrate media on the removal of arsenic, boron and iron from an acidic wastewater in planted column reactors. Chem Eng J 179:119-130

Luan Y, Ma Z, Pan L (2012) Establishion of radioactive contamination monitoring network and bioremediation of the soil around the nuclear facilities in China. Advanced Materials Research Vol.: 347-353, pp: 512-521. doi:10.4028/www.scientific.net/AMR.347353.512 Part 1-7, Book Editor(s): Pan W., Ren J.X., Li Y.G

Lumiste L, Munter R, Sutt J, Kivimäe T, Eensaluc T (2012) Removal of radionuclides from Estonian groundwater using aeration, oxidation, and filtration. Proceedings of the Estonian Academy of Sciences 61(1):58-64

Michalik B, Chałupnik S, Skubacz K (2002) Contamination of settling ponds of coal mines, caused by natural radionuclides. In: II International 
symposium on technologically enhanced natural radiation, technical report IAEA-TECDOC-1271. Vienna, IAEA

Miro C, Baeza A, Salas A, Pastor-Valle JF, Pastor-Villegas J (2008) Adsorption of 241Am and 226Ra from natural water by wood charcoal. Appl Radiat Isot 66:95-102

Nixon A, Keller D, Fritze K, Pidruczny A, Corsini A (1983) Radium removal from Elliot Lake uranium mill solids by EDTA leaching. Hydrometallurgy 10:173-186

Panek R, Franus W, Wdowin M (2011) Hydrothermal inversion of F class fly ash into synthetic zeolites. Abstract Book IS AM\&MM

Patent 1996, Polish Patent Office (Urząd Patentowy RP) - Patent nr 169869 for: method of radium removal from water", for the team of J. Lebecka

Payne KB, Abdel-Fattah TM (2005) Adsorption of arsenate and arsenite by iron treated activated carbon and zeolites: effects of $\mathrm{pH}$, temperature, and ionic strength. J Environ Sci Health A 40:723749

Ring RJ, Levins DM, Gee FJ (1982) Radionuclides in process and waste streams at an operating uranium mill. In: Management of wastes from uranium mining and milling (Proc. Int. Symp. Albuquerque, NM, 1982) IAEA, Vienna, pp. 247-261

Różkowski A (1978) Underground waters of Upper Silesian Coal Basin (in Polish), in: Polish Mining Review, Katowice

Shevade S, Ford RG (2004) Use of synthetic zeolites for arsenate removal from pollutant water. Water Res 38:3197-3204
Stehlik AJ, Friedmann H, Ein Verfahren zur selektiven Entfernung von Radium aus Wasser, Ernährung, (A technique for selective removal of radium from water, in German), Nutrition, vol. 13 Nr.3, 1989

Tomza I, Lebecka J (1981) Radium-bearing waters in coal mines: occurrence, methods of measurements and radiation hazard. International conference on radiation hazards in mining. American Institute of Mining, Metallurgical, and Petroleum Engineers Inc., Golden

UNSCEAR (2000) Sources and effects of ionizing radiation. Report of United Nations Scientific Committee on the Effects of Atomic. Radiation, New York

Varskog P, Melberg B, Aamlid H, Ramsøy T (2004) NORM in the Norwegian North Sea Sector. In: International symposium on disposal of low activity radioactive waste. 12-17 Dec 2004. Córdoba, Spain: IAEA-CN-124. pp. 136-140

Vornehm Ch (2009) Naturally occurring radioactivity in the residues of drinking water treatment - ALARA NORM Meeting, Dresden

Wang S, Peng Y (2010) Natural zeolites as effective adsorbents in water and wastewater treatment. Chem Eng J 156:11-24

Wingenfelder U, Hansen C, Furrer G, Schulin R (2005) Removal of heavy metals from mine waters by natural zeolites. Environ Sci Technol 39:4606-4613

Yang DJ, Zheng ZF, Zhu HY et al (2008) Titanate nanofibers as intelligent absorbents for the removal of radioactive ions from water. Advanced Materials 20(14):2777-2781. doi:10.1002/adma.200702055 